\title{
Performance Status and Number of Metastatic Extra-cerebral Sites Predict Survival After Radiotherapy of Brain Metastases from Thyroid Cancer
}

\author{
LIESA DZIGGEL $^{1}$, NIKLAS GEBAUER ${ }^{2}$, TOBIAS BARTSCHT ${ }^{2}$, STEVEN E. SCHILD ${ }^{3}$ and DIRK RADES ${ }^{1}$ \\ Departments of ${ }^{1}$ Radiation Oncology and Hematology and ${ }^{2}$ Medical Oncology, \\ University of Lübeck, Lübeck, Germany; \\ ${ }^{3}$ Department of Radiation Oncology, Mayo Clinic, Scottsdale, AZ, U.S.A.
}

\begin{abstract}
Background/Aim: Patients with brain metastases from thyroid cancer are extremely rare. This study evaluated clinical factors for survival following whole-brain radiotherapy (WBRT) alone. Patients and Methods: In six patients, the following factors were analyzed for survival: Regimen of WBRT (5×4 Gy vs. 10×3 Gy), gender, age ( $\leq 55$ $v s . \geq 56$ years), Karnofsky performance score (KPS) (60\% vs. 70-80\%), number of brain lesions (2-3 vs. $\geq 4)$ and number of extra-cranial metastatic sites (one vs. more than one). Results: KPS 70-80\% ( $p=0.036)$ and involvement of only one extra-cranial site $(p=0.018)$ were associated with better survival on univariate analysis. On Cox regression analysis, $\operatorname{KPS}(p=0.14)$ and number of extra-cranial sites $(p=0.14)$ showed trends for association with survival. In patients with KPS 70-80\% and only one extra-cranial site, 6-month survival was $100 \%$, no patient with KPS $60 \%$ and more than one extra-cranial site survived to 6 months. Conclusion: KPS and number of involved extra-cranial metastatic sites were associated with survival and may be helpful for individualizing therapy in patients with brain metastases from thyroid cancer.
\end{abstract}

Patients with brain metastases from thyroid cancer are extremely rare and represent fewer than $1 \%$ of all patients with metastasis from a solid tumor to the brain $(1,2)$. Therefore, only very little is known about this group of patients with cancer. The current study was conducted to add more data for patients with thyroid cancer who received

Correspondence to: Professor Dirk Rades, MD, Department of Radiation Oncology, University of Lübeck, Lübeck, Ratzeburger Allee 160, 23562 Lübeck, Germany. Tel: +49 45150045401, Fax: +49 45150045404, e-mail: rades.dirk@gmx.net

Key Words: Thyroid cancer, metastatic lesions to the brain, wholebrain radiotherapy alone, survival, predictive factors. whole-brain radiotherapy (WBRT) alone for intracerebral metastatic lesions. The main goal of this study was identification of clinical factors associated with survival. Such factors could be used to tailor treatment, in particular the radiotherapy regimen for an individual patient, taking into account the most appropriate overall treatment time.

It is generally agreed that when considering treatment effect and potential toxicities, patients with a poor survival prognosis should preferentially receive a shorter course of WBRT and those with a more favorable prognosis a longer course of WBRT (2-4). It has been shown that factors predicting survival can differ considerably between various solid tumor types which lead to brain metastases (5-13). Therefore, studies performed to identify the significant predictors separately for each tumor entity are important.

\section{Patients and Methods}

Six patients who received WBRT alone for more than one metastasis to the brain from thyroid cancer between 2000 and 2004 were included in this retrospective study and evaluated for survival. A total of six clinical factors were analyzed for a potential association with outcome following WBRT. The investigated factors included were the regimen of WBRT $(5 \times 4$ Gy over 2 weeks $v s$. $10 \times 3$ Gy over 3 weeks), gender, age at the time of WBRT $(\leq 55 \mathrm{vs}$. $\geq 56$ years, median $=55.5$ years), the Karnofsky performance score (KPS of $60 \%$ vs. $70-80 \%$, median $=65 \%$ ), the number of metastatic lesions to the brain (2-3vs. $\geq 4$, median=3) and the number of involved extra-cranial metastatic sites (one vs. more than one, median=1) (Table I). Initially, a univariate analysis of survival was performed using the Kaplan-Meier method supplemented with the log-rank test (14). Subsequently, those factors achieving significance on univariate analysis $(p<0.05)$ were investigated in a multivariate fashion (Cox regression model).

\section{Results}

The median follow-up time was 8 months (range $=1-18$ months) for the entire cohort and 12.5 months (range $=7-18$ 
Table I. Distribution of the investigated clinical factors.

\begin{tabular}{ll}
\hline & Number of patients \\
\hline Regimen of WBRT & 3 \\
$5 \times 4$ Gy over 2 weeks & 3 \\
$10 \times 3$ Gy over 3 weeks & 2 \\
Gender & 4 \\
Female & \\
Male & 3 \\
Age at WBRT & 3 \\
$\leq 55$ Years & \\
$\geq 56$ Years & 3 \\
Karnofsky performance score & 3 \\
$60 \%$ & \\
$70-80 \%$ & 3 \\
Number of metastatic brain lesions & 3 \\
$2-3$ & \\
$\geq 4$ & 4 \\
Number of extra-cranial metastatic sites & 2 \\
1 & \\
$>1$ &
\end{tabular}

WBRT: Whole-brain-radiotherapy.

months) for the patients who were alive at their last followup. For the entire cohort, the survival rates at 6 and 12 months were $67 \%$ and $44 \%$, respectively. On univariate analysis, a KPS of $70-80 \%$ ( $v s .60 \%, p=0.036$ ) and involvement of only one extra-cranial metastatic site ( $v s$. more than on site, $p=0.018$ ) were significantly associated with survival (Table II). In the subsequent Cox regression analysis, both KPS $(p=0.14)$ and number of extra-cranial metastatic sites $(p=0.14)$ showed trends for associations with survival.

The importance of these two clinical factors is further supported by the finding that patients with a KPS of 70$80 \%$ and involvement of only one extra-cranial metastatic site achieved a 6-month survival rate of $100 \%$, whereas those patients with a KPS of $60 \%$ and involvement of more than one extra-cranial metastatic site had a 6-month survival rate of $0 \%$.

\section{Discussion}

Thyroid cancer is considered an important disease, and considerable research has been performed to improve the prognoses of these patients. Clinical studies have been reported on surgical techniques, novel systemic treatments and multidisciplinary approaches (15-17). Another field of research aims to identify prognostic factors that allow clinicians to better judge a patient's prognosis, which is important for designing individualizing therapy. Prognostic factors have already been identified for treatment of the
Table II. Univariate analyses: survival rates at 6 and 12 months following WBRT.

\begin{tabular}{|c|c|c|c|}
\hline & $\begin{array}{c}\text { At } 6 \\
\text { months, } \\
\%\end{array}$ & $\begin{array}{c}\text { At } 12 \\
\text { months, } \\
\%\end{array}$ & $p$-Value \\
\hline \multicolumn{4}{|l|}{ Regimen of WBRT } \\
\hline $5 \times 4$ Gy over 2 weeks $(n=3)$ & 67 & 0 & \\
\hline $10 \times 3$ Gy over 3 weeks $(n=3)$ & 67 & 67 & 0.36 \\
\hline \multicolumn{4}{|l|}{ Gender } \\
\hline Female $(\mathrm{n}=2)$ & 100 & 100 & \\
\hline Male $(n=4)$ & 50 & 25 & 0.11 \\
\hline \multicolumn{4}{|l|}{ Age at WBRT } \\
\hline$\leq 55$ Years $(n=3)$ & 67 & 67 & \\
\hline$\geq 56$ Years $(\mathrm{n}=3)$ & 67 & 0 & 0.50 \\
\hline \multicolumn{4}{|l|}{ Karnofsky performance score } \\
\hline $60 \%(n=3)$ & 33 & 0 & \\
\hline $70-80 \%(\mathrm{n}=3)$ & 100 & 100 & 0.036 \\
\hline \multicolumn{4}{|l|}{ Number of metastatic brain lesions } \\
\hline $2-3(n=3)$ & 33 & 33 & \\
\hline$\geq 4(n=3)$ & 100 & 50 & 0.79 \\
\hline \multicolumn{4}{|c|}{ Number of extra-cranial metastatic sites } \\
\hline $1(\mathrm{n}=4)$ & 100 & 67 & \\
\hline$>1(\mathrm{n}=2)$ & 0 & 0 & 0.018 \\
\hline Entire cohort & 67 & 44 & \\
\hline
\end{tabular}

WBRT: Whole-brain-radiotherapy, significant $p$-values are shown in bold.

primary tumor and also for metastatic disease (18-23). However, to our knowledge no study exists focusing on patients with thyroid cancer who require treatment for metastases to the brain. The most frequently used treatment modality for brain metastases is WBRT, either alone or combined with focal therapies such as neurosurgical resection and stereotactic radiosurgery (2). This study focused particularly on patients treated with WBRT alone.

In this study, two predictors of survival, namely the KPS and number of extra-cranial metastatic sites, were identified on univariate analyses. The prognostic value of the performance status for patients receiving treatment for brain metastases has been described for other tumors and was found to be prognostic for this cohort. The prognostic impact of the number of extra-cranial metastatic sites has been found prognostic in a few studies, mainly in patients with brain metastases from breast cancer or lung cancer (24-27).

Taking into account the retrospective design of the present study and the small number of patients evaluated, the results of the present study may serve to guide clinicians when they aim to tailor the radiation treatment to a patient with metastases to the brain from thyroid cancer. Since no patient with a KPS of only $60 \%$ and metastatic involvement of more than one extra-cranial site survived longer than 4 months, these patients appear good candidates for short-course 
WBRT with $5 \times 4$ Gy over 1 week, which has shown to be non-inferior to longer-course WBRT programs with 30-40 Gy over 2-4 weeks (3). In contrast, patients with the most favorable survival prognosis (KPS $>60 \%$ and involvement of maximum one extra-cranial site) could benefit from longercourse WBRT programs with higher total doses in terms of better intracerebral control and survival (4). Patients of the latter group with a limited number of cerebral lesions may also be good candidates for focal therapies (2).

In conclusion, in this study, the KPS and the number of involved extra-cranial metastatic sites were identified to be associated with survival in patients receiving WBRT alone for brain metastases from thyroid cancer. Although this study was small, these two factors could be used for personalization of care for this patient group.

\section{Conflicts of Interest}

On behalf of all Authors, the corresponding Author states that there is no conflict of interest related to this study.

\section{References}

1 Siegel RL, Miller KD and Jemal A: Cancer statistics, 2017. CA Cancer J Clin 67: 7-30, 2017.

2 Tsao MN, Rades D, Wirth A, Lo SS, Danielson BL, Gaspar LE, Sperduto PW, Vogelbaum MA, Radawski JD, Wang JZ, Gillin MT, Mohideen N, Hahn CA and Chang EL: Radiotherapeutic and surgical management for newly diagnosed brain metastasis(es): An American Society for Radiation Oncology evidence-based guideline. Pract Radiat Oncol 2: 210-225, 2012.

3 Rades D, Kieckebusch S, Lohynska R, Veninga T, Stalpers LJ, Dunst $\mathrm{J}$ and Schild SE: Reduction of overall treatment time in patients irradiated for more than three brain metastases. Int $\mathrm{J}$ Radiat Oncol Biol Phys 69: 1509-1513, 2007.

4 Rades D, Panzner A, Dziggel L, Haatanen T, Lohynska R and Schild SE: Dose-escalation of whole-brain radiotherapy for brain metastasis in patients with a favorable survival prognosis, Cancer 118: 3853-3859, 2012.

5 Dziggel L, Schild SE, Veninga T, Bajrovic A and Rades D: Clinical factors asssociated with treatment outcomes following whole-brain irradiation in patients with prostate cancer. In Vivo 31: 35-38, 2017.

6 Sehmisch L, Schild SE and Rades D: Development of a survival score for patients with cerebral metastases from melanoma. Anticancer Res 37: 249-252, 2017.

7 Rades D, Bartscht T and Schild SE: Predictors of survival in patients with brain metastases from gastric cancer. Neoplasma 64: 136-139, 2017.

8 Rades D, Schild SE, Lohynska R, Veninga T, Stalpers LJ and Dunst J: Two radiation regimens and prognostic factors for brain metastases in non-small cell lung cancer patients. Cancer 110: 1077-1082, 2007.

9 Rades D, Lohynska R, Veninga T, Stalpers LJ and Schild SE: Evaluation of 2 whole-brain radiotherapy schedules and prognostic factors for brain metastases in breast cancer patients. Cancer 110: 2587-2592, 2007.
10 Rades D, Fischer D, Veninga T, Stalpers LJ and Schild SE: Prognostic factors for survival and intracerebral control after irradiation for brain metastases from gynecological cancer. Gynecol Oncol 114: 506-508, 2009.

11 Rades D, Dziggel L, Bartscht T and Gliemroth J: Predicting overall survival in patients with brain metastases from esophageal cancer. Anticancer Res 34: 6763-6765, 2014.

12 Rades D, Dziggel L, Hakim SG, Rudat V, Janssen S, Trang NT, Khoa MT and Bartscht T: Predicting survival after irradiation for brain metastases from head and neck cancer. In Vivo 29: 525$528,2015$.

13 Rades D, Dziggel L, Veninga T, Bajrovic A and Schild SE: Overall survival after whole-brain radiation therapy for intracerebral metastases from testicular cancer. Anticancer Res 36: 4817-4819, 2016.

14 Kaplan EL and Meier P: Non parametric estimation from incomplete observations. J Am Stat Assoc 53: 457-481, 1958.

15 Damaskos C, Garmpis N, Valsami S, Spartalis E, Antoniou EA, Tomos P, Karamaroudis S, Zoumpou T, Pergialiotis V, Stergios $\mathrm{K}$, Michaelides C, Kontzoglou K, Perrea D, Nikiteas N and Dimitroulis D: Histone deacetylase inhibitors: A novel therapeutic weapon against medullary thyroid cancer? Anticancer Res 36: 5019-5024, 2016.

16 Käsmann L, Bolm L, Janssen S and Rades D: Prognostic factors for survival in patients treated with multimodal therapy for anaplastic thyroid cancer. Anticancer Res 36: 4697-4700, 2016.

17 Megwalu UC and Green RW: Total thyroidectomy versus lobectomy for the treatment of follicular thyroid microcarcinoma. Anticancer Res 36: 2899-2902, 2016.

18 Rades D, Janssen S, Käsmann L, Bolm L and Schild SE: Outcomes after irradiation of epidural spinal cord compression due to metastatic thyroid cancer. Anticancer Res 36: 2035-2039, 2016.

19 Do SI, Kim HS, Kim K, Lee H, Do IG, Kim DH, Chae SW and Sohn JH: Predictive value of sphingosine kinase 1 expression in papillary thyroid carcinoma. Anticancer Res 37: 5399-5405, 2017.

20 Wojtczak B, Pula B, Gomulkiewicz A, Olbromski M, Podhorska-Okolow M, Domoslawski P, Bolanowski M, Daroszewski $\mathrm{J}$ and Dziegiel P: Metallothionein isoform expression in benign and malignant thyroid lesions. Anticancer Res 37: 5179-5185, 2017.

21 Karagiannis AK, Girio-Fragkoulakis $\mathrm{C}$ and Nakouti T: Procalcitonin: A new biomarker for medullary thyroid cancer? A systematic review. Anticancer Res 36: 3803-3810, 2016.

22 Londero SC, Jespersen ML, Krogdahl A, Bastholt L, Overgaard J, Schytte S, Godballe C and Alsner J; study from The Danish Thyroid Cancer Group-DATHYRCA (part of the DAHANCA organization): Gene-expression classifier in papillary thyroid carcinoma: Validation and application of a classifier for prognostication. Anticancer Res 36: 749-756, 2016.

23 Masudo K, Suganuma N, Nakayama H, Oshima T, Rino Y, Iwasaki H, Matsuzu K, Sugino K, Ito K, Kondo T, Nakamura Y, Yoshihara M, Masuda M and Miyagi Y: EZH2 overexpression as a useful prognostic marker for aggressive behaviour in thyroid cancer. In Vivo 32: 25-31, 2018.

24 Rades D, Gerdan L, Segedin B, Nagy V, Khoa MT, Trang NT and Schild SE: Brain metastasis. Prognostic value of the number of involved extracranial organs. Strahlenther Onkol 189: 9961000,2013 
25 Gerdan L, Segedin B, Nagy V, Khoa MT, Trang NT, Schild SE and Rades D: The number of involved extracranial organs: a new predictor of survival in breast cancer patients with brain metastasis. Clin Neurol Neurosurg 115: 2108-2110, 2013.

26 Gerdan L, Šegedin B, Veninga T, Schild SE and Rades D: Number of involved extracranial organs predicts survival in patients with brain metastasis from small cell lung cancer. Anticancer Res 33: 3887-3889, 2013.
27 Gerdan L, Segedin B, Nagy V, Khoa MT, Trang NT, Schild SE and Rades D: Brain metastasis from non-small cell lung cancer (NSCLC): prognostic importance of the number of involved extracranial organs. Strahlenther Onkol 190: 64-67, 2014.

Received January 15, 2018

Revised February 9, 2018

Accepted February 13, 2018 